\title{
Pemahaman Kualitatif Siswa Terhadap Konsep Fluida Statis
}

\author{
Amaliya Putri, Jusman Mansyur, dan Sahrul Saehana \\ Jusmansyurfis@yahoo.com \\ Program Studi Pendidikan Fisika FKIP Universitas Tadulako \\ Jl. Soekarno Hatta Km. 9 Kampus Bumi Tadulako Tondo Palu - Sulawesi Tengah
}

\begin{abstract}
Abstrak - Penelitian ini bertujuan untuk mendeskripsikan pemahaman kualitatif siswa pada konsep fluida statis. Penelitian ini dilakukan di SMA Negeri 1 Palu. Subyek penelitian pada siswa kelas X MIA 3 yang terdiri dari 33 orang. Responden pada penelitian ini berjumlah 6 orang dengan 2 kategori kemampuan tinggi, sedang, dan rendah yang diperoleh dari hasil pemberian Tes Seleksi Responden (TSR). Data penelitian diperoleh melalui lembar jawaban siswa, rekaman thinking-aloud dan wawancara. Data penelitian ini dianalisis melalui pendekatan deskriptif-kualitatif. Hasil penelitian menunjukan bahwa hampir semua responden memiliki tingkat pemahaman kualitatif dalam kategori rendah (tidak memahami) disebabkan karena siswa lebih sering diberikan soal perhitungan dibandingkan soal pemahaman konsep.
\end{abstract}

Kata Kunci: Pemahaman Kulaitatif, Fluida Statis

\section{PENDAHULUAN}

Pendidikan pada dasarnya merupakan proses untuk membantu manusia dalam mengembangkan potensi dirinya sehingga mampu menghadapi setiap perubahan yang terjadi. Pendidikan juga merupakan proses pengubahan sikap dan tatalaku seseorang atau kelompok orang dalam usaha mendewasakan manusia melalui upaya pengajaran dan pelatihan.

Fisika merupakan salah satu mata pelajaran yang diujiankan dalam ujian nasional. Selama ini, soal yang diujiankan dalam ujian nasional adalah soal pilihan ganda. Penggunaan soal pilihan ganda terkadang menggabungkan beberapa konsep dalam satu pertanyaan ataupun jawaban yang dapat memicu siswa berbuat kira-kira dalam mengerjakan soal sehingga nilai yang diperoleh dalam ujian nasional belum mampu mengambarkan secara rinci bagaimana pemahaman konsep siswa pada mata pelajaran fisika [1].

Belajar untuk menyelesaikan masalah dalam bidang ilmiah seperti fisika, membutuhkan pemahaman konsep. Namun, apabila siswa tidak memahami konsep terhadap suatu materi, mengakibatkan terjadinya miskonsepsi maupun kesalahan konsep.

Penelitian tentang pemahaman kualitatif siswa untuk masalah fisika menunujukan bahwa kelemahan yang sangat serius dalam pemahaman siswa mengenai konsep pada materi yang diajarkan [2]. Kelemahan juga ditemukan di kompetensi guru non-fisika yang mengajar konsep fisika. Beberapa kesalahan konsep siswa didukung dan diperkuat oleh buku pelajaran fisika dan guru yang tidak memiliki latar belakang pendidikan fisika, tapi mengajarkan dasar konsep fisika.

Penelitian tentang pemahaman kualitatif yang telah ada yaitu hukum II Newton [3], konsep massa [4], konsep termo-mekanik [5]. Khusus untuk pemahaman kualitatif siswa pada konsep fluida statis hanya sedikit penelitian yang telah dilakukan tentang konsep tersebut salah satunya adalah penelitian tentang aliran fluida [6].

\section{METODE PENELITIAN}

Penelitian ini mendeskripsikan pemahaman kualitatif siswa pada konsep fluida statis menggunakan soal essay yang didukung dengan wawancara.

Subjek penelitian ini adalah siswa kelas $X$ MIA 3 SMA Negeri 1 Palu Tahun Ajaran 2017/2018 yang berjumlah 33 siswa dan responden dalam penelitian ini berjumlah 6 siswa.

Responden dipilih berdasarkan nilai TSR yang diperoleh yakni 2 siswa dengan kategori kemampuan tinggi, 2 siswa dengan kategori kemampuan sedang dipilih secara random, dan 2 siswa dengan kategori kemampuan rendah.

Hasil pengolahan data, nilai rata-rata yang diperoleh adalah 54,74 dan nilai standar deviasi adalah 7,39. Berdasarkan kategori tersebut dipilih 2 (tiga) orang dari masing-masing kategori tinggi, sedang, dan rendah yang akan diberikan tes essay serta diwawancarai dengan mempertimbangkan hasil jawaban yang diberikan pada tes essay konsepsi siswa. Kode dan kategori responden dapat diamati pada Tabel 1. 
TABEL 1 KODE DAN KATEGORI RESPONDEN

\begin{tabular}{lllc}
\hline No & Inisial Siswa & Kategori & $\begin{array}{c}\text { Kode } \\
\text { Kategori }\end{array}$ \\
\hline 1 & R-07 & Tinggi & RT-01 \\
2 & R 15 & Tinggi & RT-02 \\
3 & R-09 & Sedang & RS-03 \\
4 & R-27 & Sedang & RS-04 \\
5 & R-08 & Rendah & RR-05 \\
6 & R-02 & Rendah & RR-06 \\
\hline
\end{tabular}

\section{HASIL DAN PEMBAHASAN}

Tujuan utama penelitian adalah untuk mendeskripsikan pemahaman kualitatif siswa terhadap konsep fluida statis. Perangkat instrumen yang digunakan dalam penelitian ini yaitu TSR, tes essay, dan wawancara.

Penentuan responden ini diperoleh dari hasil Tes Seleksi Responden (TSR) yang dibagi menjadi 3 kategori kemampuan siswa yaitu kategori tinggi, sedang dan rendah. Kemudian dari ketiga kategori tersebut dipilih enam orang sebagai responden berdasarkan skor. Pemilihan keenam responden tersebut bertujuan untuk menggambarkan keragaman kemampuan yang dimiliki siswa. Keenam responden tersebut akan diberikan tes berupa tes TA dan wawancara yang berkaitan dengan materi fluida statis.

\section{A. Responden Kategori Tinggi}

Responden dengan kategori kemampuan tinggi diperoleh dari hasil TSR yaitu RT-1 dan RT-2. Analisis soal fluida statis untuk konsep hukum Archimedes pada sepotong besi yang menempel pada kayu yang mengapung. Hasil penelitian menunjukan untuk responden RT-1 menjawab salah untuk untuk konsep hukum Archimedes pada sepotong besi yang menempel pada kayu yang mengapung. Tingkat pemahaman konsep responden masih tergolong rendah. Kutipan jawaban responden disajikan pada Gbr 1.

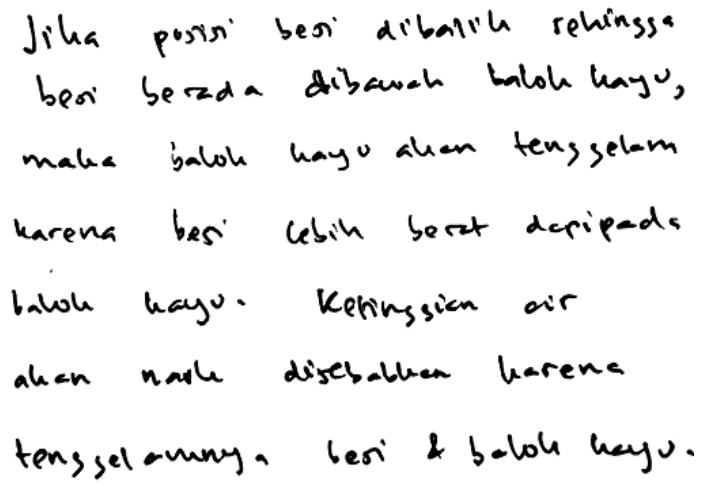

Gbr 1. Kutipan jawaban RT-1

RT-1 memahami dengan baik konsep hukum Archimedes di mana suatu benda tenggelam apabila massa jenis benda tersebut lebih besar dari massa jenis zat cair dan suatu benda tenggelam apabila massa jenis benda lebih kecil dari massa jenis zat cair. RT-1 tidak dapat menjelaskan dan memberikan jawaban yang tepat disebabkan karena RT-1 tidak memahami soal dengan baik.

Untuk soal fluida stais lainnya disajikan pada Gbr 2 dan Gbr 3.

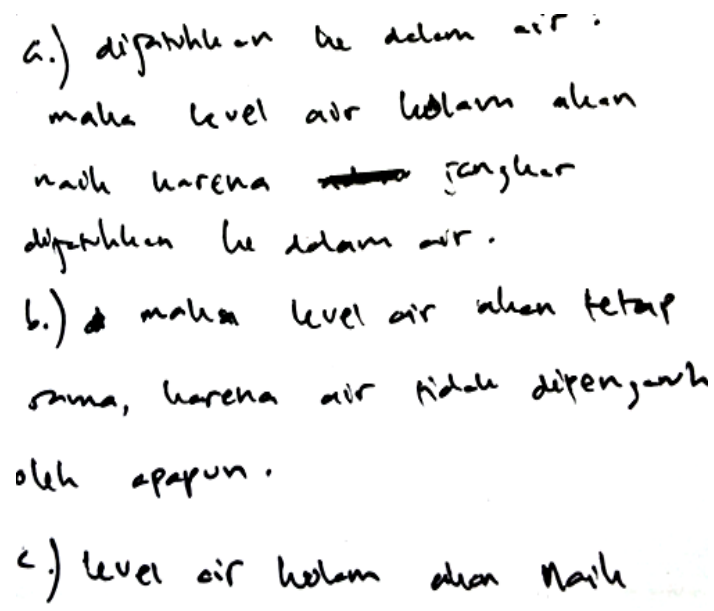

Gbr 3. Kutipan Jawaban RT-1

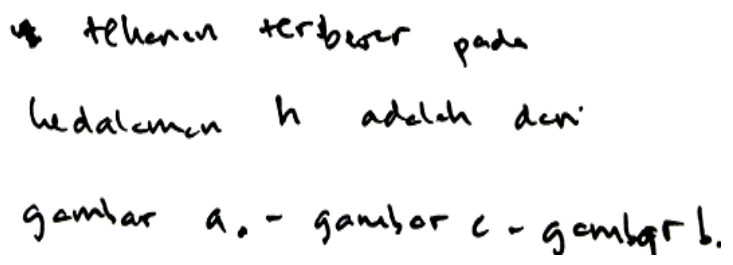

Gbr 4. Kutipan Jawaban RT-1

RT-1 kurang memahami maksud untuk konsep fluida statis dari masing-masing konteks di atas. Hal itu disebabkan karena RT-1 tidak menguasai konsep fluida statis. Hasil yang diperoleh sesuai dengan penelitian yang dilakukan sebelumnya [8] yang menyimpulkan bahwa penyebab pemahaman konsep siswa yang rendah yaitu siswa sulit untuk memahami soal yang berhubungan dengan pemahaman konsep.

Responden dengan kategori tinggi lainnya adalah RT-2 menjawab salah untuk konsep hukum Archimedes pada sepotong besi yang menempel pada kayu yang mengapung. Kutipan jawaban responden disajikan pada Gambar 5.

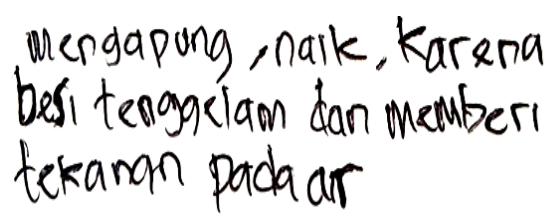

Gbr 5. Kutipan Jawaban RT-2 
Gambar 5 menunjukkan bahwa jawaban RT-2 tergolong memahami konsep. Namun responden tidak memahami soal dengan baik. Pada soal dijelaskan bahwa pada peristiwa tersebut, besi menempel pada kayu namun responden memahami bahwa besi tidak menempel pada kayu sehingga jawaban responden menyatakan bahwa saat posisi dibalik dimana balok kayu berada di atas dan besi berada di bawah, balok kayu akan mengapung dan besi akan tenggelam.

RT-2 sangat memahami konsep fluida statis untuk peristiwa pipa $U$ yang berada dalam kesetimbangan statis. Kutipan jawaban responden disajikan pada Gbr 6 .

$$
\begin{aligned}
\text { a no } 2 & \\
\text { b no 1 }= & \text { merah lebih } \\
& \text { keal dari pada } \\
& \text { dou abu } \\
\text { no } 3= & \text { merah Sama } \\
& \text { dergan aburabu } \\
\text { no } 4= & \text { Merah lebih } \\
& \text { besar dari } \\
& \text { abu-abu. }
\end{aligned}
$$

Gbr 6. Kutipan Jawaban RT-2

Soal fluida stais lainnya disajikan pada Gbr 7, Gbr 8 dan Gbr 9.

Level air kolam akan naik maka level air mesurun, texap Sama, karena tckanan yang diberikán kayy pada saat kaya berada di atas peratiu sama dengan zekaran yang diberikari pada saat kasju

Gbr 7. Kutipan Jawaban RT-2

$$
a-c-b
$$

Gbr 8. Kutipan Jawaban RT-2

Gaya yañg diberikan pada penampang 1 keell dan mamberikan dampak yang besar terkadap Penampang II

Gbr 9. Kutipan jawaban RT-2
RT-2 kurang memahami soal untuk konsep fluida statis dari masing-masing konteks di atas. RT-2 banyak mengalami kesalahan konsep mengenai konsep fluida statis. Hasil yang diperoleh sesuai dengan penelitian yang dilakukan sebelumnya [4] yang menyimpulkan bahwa banyak siswa yang mengalami kesalahan konsep dasar mengenai suatu konsep.

\section{B. Responden Kategori Sedang}

Responden kategori sedang RS-3, dan RS-4 dapat mengerjakan soal konsep kelembaman untuk konsep fluida statis. Hasilnya menunjukan untuk responden RS-3 pada konsep fluida statis tergolong cukup memahami konsep. Kutipan jawaban responden dapat dilihat pada Gbr 10, dan Gbr 1.

menurut, jika besi diletukan dibawah maka benda

akan tenggelam, ketinggian airnya akan aik karena balok tersebut tenggelam.

Gbr 10. Kutipan Jawaban RS-3

menurut saya, proses

tersebut dap terjadi

aleibat gaya yang

cukup besar dari $F_{1}$ sehingara

mempeng aruhi gaya $F_{2}$.

Gbr 11. Kutipan Jawaban RS-3

Kutipan jawaban responden lainnya untuk soal fluida statis disajikan pada Gbr 12, Gbr 13, Gbr 14 dan Gbr 15.

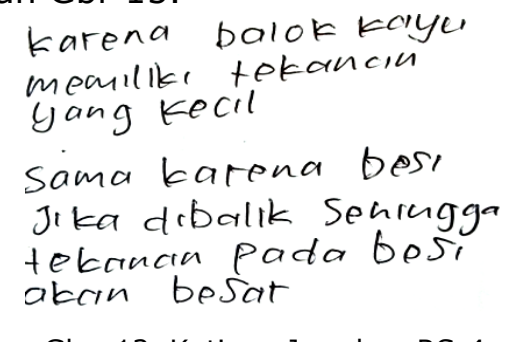

Gbr 12. Kutipan Jawaban RS-4

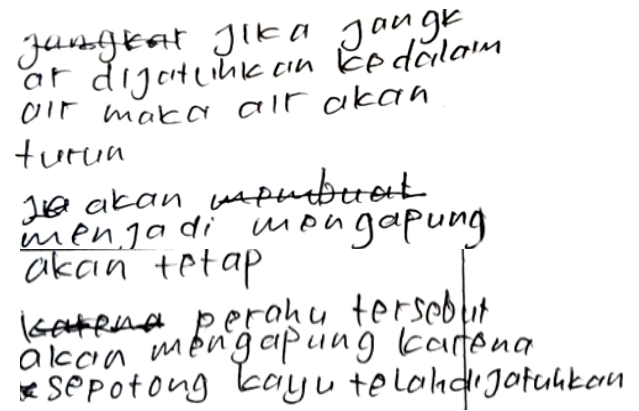

Gbr 13. Kutipan jawaban RS-4 


\section{$a, 0, b$}

Gbr 14. Kutipan Jawaban RS-4

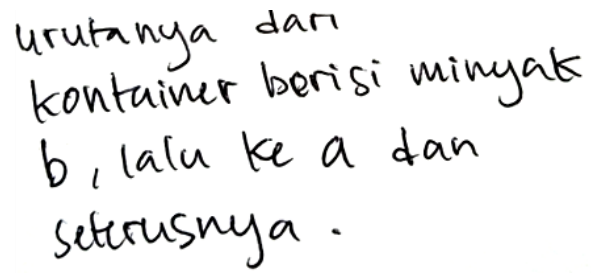

Gbr 15. Kutipan Jawaban RS-3

Kutipan jawaban responden dapat dinyatakan bahwa responden tidak memahami konsep fluida statis dari masing-masing konteks di atas. Pada konsep tekanan responden beranggapan bahwa faktor yang mempengaruhi tekanan adalah bentuk wadah zat cair. RS-3 dan RS-4 banyak mengalami kesalahan konsep mengenai konsep fluida statis. Hasil yang diperoleh sesuai dengan penelitian yang dilakukan sebelumnya [4] yang menyimpulkan bahwa banyak siswa yang mengalami kesalahan konsep dasar mengenai suatu konsep.

RS-3 dan RS-4 kurang memahami konsep tekanan Hidrostatis pada pipa $U$ dalam kesetimbangan statis disebabkan karena siswa lebih sering diberikan soal perhitungan dibandingkan soal pemahaman konsep. Kutipan jawaban responden disajikan pada Gbr 16, dan Gbr 17.

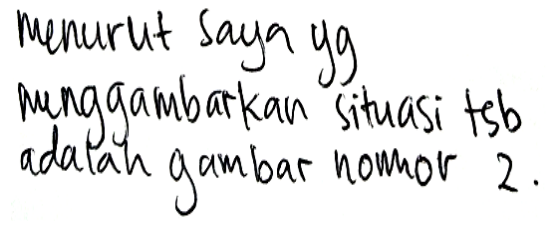

Gbr 16. Kutipan Jawaban RS-3

$$
\begin{aligned}
& \text { Gambar } 2 \\
& \text { akan sama }
\end{aligned}
$$

Gbr 17. Kutipan Jawaban RS-4

\section{Responden Kategori Rendah}

Responden kategori rendah RR-5 dan RR-6 dapat mengerjakan soal konsep fluida statis. Untuk soal fluida statis pada konsep hukum Archimedes pada sepotong besi yang menempel pada kayu yang mengapung RR-5 tergolong dalam kategori kurang memahami dan RR- 6 tergolong dalam kategori memahami. Kutipan jawaban responden disajikan pada $\mathrm{Gbr}$ 18 dan Gbr 19.

\section{tenggelam kareno} hes mempunyai massa berat yang lesih herat dan' balok. ketrnggianair akan haik. karena ofomatis besiyons nerada dihalor akan menuruth jadi air yang berada didalart wadah akan nairs.

Gbr 18. Kutipan Jawaban RR-5

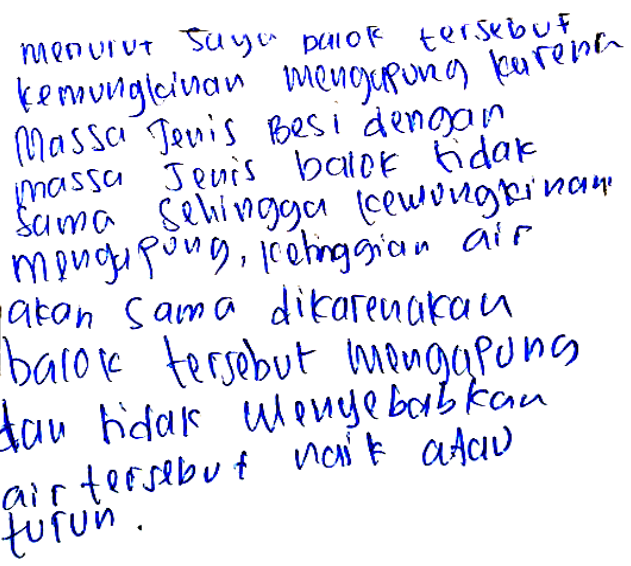

Gbr 19. Kutipan Jawaban RR-6

Hasil wawancara menunjukkan bahwa RR-5 memahami dengan baik konsep hukum Archimedes dimana suatu benda tenggelam apabila massa jenis benda tersebut lebih besar dari massa jenis zat cair dan suatu benda tenggelam apabila massa jenis benda lebih kecil dari massa jenis zat cair namun RR-5 tidak dapat menjelaskan dan memberikan jawaban yang tepat. RR- 6 kurang memahami konsep hukum Archimedes serta kurangnya pemahaman terhadap konsep soal. Hasil yang diperoleh sesuai dengan penelitian yang dilakukan sebelumnya [8]. Penyebab dari pemahaman konsepsi siswa yang rendah yaitu siswa sulit untuk memahami soal yang berhubungan dengan pemahaman konsep.

Untuk soal fluida stais lainnya disajikan pada Gbr 19 dan Gbr 20.

\section{a. Gambar nomor 4}

b. letrin keail dañ massa Jenis cairan abu-abu

Gbr 19. Kutipan Jawaban RR-5

$$
a-c-b
$$

Gbr 20. Kutipan Jawaban RR-5 


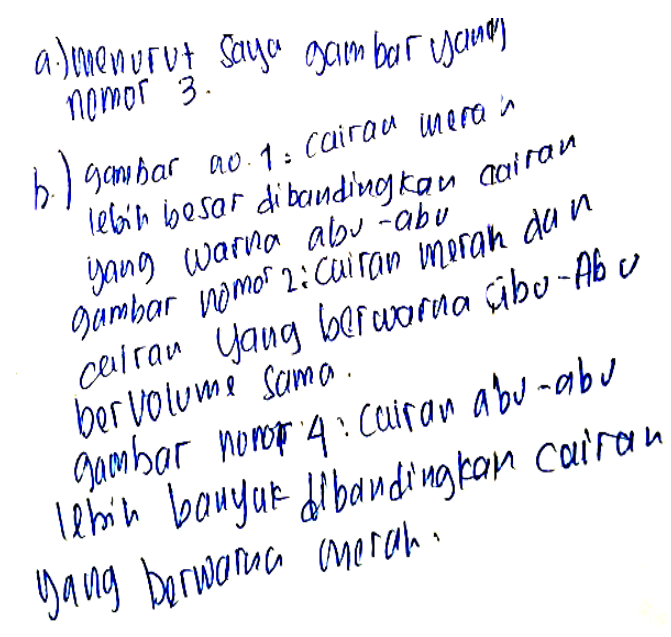

Gbr 21. Kutipan Jawaban RR-6

vertan dari yang terbesar difurjutean pada nomor c. karena luas penamparany yang lebih dulam.

\section{Gbr 22. Kutipan Jawaban RR-6}

Kutipan jawaban responden dapat dinyatakan bahwa RR-5 dan RR-6 tidak memahami konsep fluida statis sehingga menyebabkan terjadi kekeliruan dalam menjawab soal. Kemungkinan disebabkan oleh kurangnnya pemahaman terhadap soal konsep. Penguasaan konsep siswa masih tergolong rendah. Hasil yang diperoleh sesuai dengan penelitian yang dilakukan sebelumnya [9] bahwa penguasaan konsep siswa dalam menguasai konsep fluida statis masih tergolong rendah. Siswa juga masih perlu memahami konsep fluida statis yang sebenarnya.

Berdasarkan hasil analisa data pada konsepsi siswa tentang pemahaman kualitatif siswa terhadap konsep fluida statis memiliki pemahaman konsep yang beragam. penelitian yang telah dilakukan pada enam responden dalam tiga kelompok kategori kemampuan siswa yaitu kategori tinggi RT-1 dan RT-2, kategori sedang RS-3 dan RS-4, dan kategori rendah RR-5 dan RR-6. Hasilnya menunjukkan bahwa sebagian besar responden memiliki pemahaman kualitatif dalam kategori tidak memahami konsep.

Pada penelitian ini juga siswa kurang memahami soal-soal pemahaman konsep, keadaan ini terjadi karena siswa lebih dominan diberikan soal perhitungan dibanding soal pemahaman konsep.

Hasil yang diperoleh sesuai dengan penelitian yang dilakukan sebelumnya [8] bahwa penyebab dari pemahaman konsep siswa yang rendah yaitu siswa susah untuk memahami soal yang berhubungan dengan pemahaman konsep.

Salah satu penyebab rendahnya konsepsi siswa yaitu karena siswa lebih dominan diberikan soal-soal perhitungan sehingga membuat siswa rendah dalam konsep fisika.

\section{KESIMPULAN DAN SARAN}

Berdasarkan analisis data yang telah dilakukan pada konsepsi yang dimiliki siswa materi fluida statis yang diberikan dalam bentuk essay tes sebanyak 5 nomor, dapat disimpulkan bahwa kategori tinggi RT-1, dan RT-2, kategori sedang RS-3, dan RS-4, dan kategori rendah RR-5 dan RR-6. Hasil penelitian menunjukkan bahwa pemahaman kualitatif siswa pada konsep fluida statis sebagian besar responden masuk dalam kategori tidak memahami konsep. Salah satu penyebab rendahnya pemahaman konsep siswa karena siswa lebih dominan diberikan soal-soal perhitungan sehingga membuat siswa rendah dalam konsep fisika.

\section{DAFTAR PUSTAKA}

[1] Karyosumito, A. (2011). Analisis Model Penalaran Siswa SMA tentang Hukum III Newton. Skripsi FKIP Untad Palu: tidak diterbitkan

[2] Gonzalez. et al. (2008). Teachers who left the teaching profession: $A$ qualitative understanding. The Qualitative Report, 13(1), 1-11.

[3] Gates, J. (2014). Experimentally Building a Qualitative Undestanding of Newton's Second Law. .Journal of physic teachers .52,(9), 542-543

[4] Stamenkovski \& Zajkov. (2014). Seventh Grade Students' Qualitative Understanding of the Concept of Mass Influenced by Real Experiments and Virtual Experiments. European J of Physics Education.

[5] Mabrouki, B. (2006). A Contribution to a Qualitative Understanding of Termo-mechanical Effect During Chip Formation in Hard Turning. Journal of Material Processing Technology. 176, 1-3.

[6] Yohana, E. (2000). Studi Karakteristik Aliran Fluida Non Newtonian. Rotasi, 2(4) : 5-7.

[7] Sukmadinata, N. (2010). Metode Penelitian Pendidikan. Bandung: PT. Remaja Rosda karya.

[8] Saripah, K. M. (2014). Analisis Pemahaman Siswa Tentang Momen Inersia Pada Siswa Kelas XI SMA Negeri 1 Biromaru. Skripsi FKIP Untad Palu: tidak diterbitkan

[9] Yadaeni, A, Kusairi, S. (2016). "Studi Kesulitan Siswa dalam Menguasai Konsep Fluida Statis". FMIPA Universitas Negeri Malang. ISBN 978-602-9286-21 